УДК 332.834.6(477)

(C) 2014

Литвин О. Ю., кандидат економічних наук

Полтавська державна аграрна академія

\title{
ОПИСОВО-ПРОПАГАНДИСТСЬКИЙ ПЕРІОД У РОЗВИТКУ ЖИТЛОВОЇ КООПЕРАЦЇ̈
}

\section{Рецензент - доктор економічних наук, професор А. О. Пантелеймоненко}

Розглянуто основні проблеми розвитку житлової кооперації, їх висвітлення у світовій економічній літературі. Здійснено аналіз досліджень, присвячених названій темі. Запропоновано періодизаџію публікаиій, щзо окреслює чотири періоди і враховує специфріку державної політики у галузі житлової кооперації. Акцентовано увагу на тому, щзо саме житлова коопераиія може бути одним із можливих механізмів вирішення гострої житлової проблеми в Україні, на необхідності широкого інформування населення про великий потенцііал житлової кооперації та використання позитивного закордонного досвіду.

Ключові слова: кооперачія, житловий кооператив, житлово-орендний кооператив, квартира, житло.

Постановка проблеми. Важливим показником рівня соціально-економічного розвитку будь-якої держави $є$ забезпеченість iï громадян доступним і якісним житлом. Разом із тим, міжнародний досвід переконливо свідчить про те, що житлове питання $є$ одним із найскладніших для вирішення через потребу у значних фінансових ресурсах. Тому навіть у провідних країнах світу розв'язання житлової проблеми потребувало значного періоду часу, а у більшості пострадянських держав цей процес триває й нині.

До числа останніх належить Україна, де, через нестачу необхідних бюджетних коштів, існує необхідність пошуку ефективних механізмів поєднання зусиль держави 3 використанням потенціалу випробуваних світовою практикою різноманітних форм економічної самодопомоги громадян для реалізації їх конституційного права на житло та гідні умови проживання. Багаторічний вітчизняний та зарубіжний досвід житлової кооперації є особливо актуальним для нашої країни сьогодні, в умовах пошуку дієвих механізмів для забезпечення українців новим і якісним житлом, утримання його та прибудинкових територій у належному стані.

Аналіз останніх досліджень і публікацій, у яких започатковано розв'язання проблеми. Досліджень, присвячених названій темі, небагато і відображають вони лише окремі аспекти житлової кооперації. Так, С. Бородаєвский [1],
А. Меркулов [6] і Д. Полупанов [8] аналізують житлову кооперацію в Російській імперії та країнах Центральної і Східної Свропи, а М. Бройдо [2], Л. Щеглова [10] - в країнах Західної Європи. Вебб К. [3] зробила аналітичний огляд історії, теорії та практики кооперативного руху в Англії, Шотландії та Ірландії. Сам термін «кооперація» аналізує Є. Левин [5].

Проте немає узагальнення і глибокого комплексного аналізу досвіду житлової кооперації вітчизняними науковцями. Окремі аспекти, наприклад, діяльність житлово-орендних кооперативів, вивчена недостатньо. Саме це й визначає актуальність даної статті.

Мета дослідження: інформування населення про значний потенціал житлових кооперативів i позитивний досвід їх функціонування - як на українських землях, так і за кордоном - для пошуку механізмів вирішення сучасної житлової проблеми в Україні.

Найважливішим завданням дослідження $\epsilon$ аналіз публікацій, присвячених розвитку житлової кооперації.

Матеріали та методи дослідження. Для досягнення поставленої мети використані принципи системного аналізу економічних процесів, характерних для періоду становлення житлової кооперації, та фундаментальні положення інституціональної економічної теорії, передусім, теорії економічних організацій (зокрема, житлових кооперативів). Для побудови логіки й структури роботи застосовувалися методи періодизації та структурно-логічного аналізу. Методи історикоретроспективного та причинно-наслідкового аналізу були основними у ході дослідження становлення житлової кооперації. Методи комплексного й системного підходу застосовувалися нами на етапі формулювання висновків.

Результати досліджень. Беручи за основу періодизацію сучасного українського дослідника кооперативного руху А. О. Пантелеймоненка, яка висвітлює проблеми розвитку сільськогосподарської кооперації [7, с. 15], можна запропонувати аналогічну, що відображає специфіку вітчизняних публікацій щодо житлової коопера- 


\section{EKOHOMIKA}

ції, значною мірою пов'язан зі змінами у державній економічній політиці. Названа періодизація умовно охоплює чотири основні періоди:

I - описово-пропагандистський (кінець XIX початок XX ст.);

II - політизації ідеї житлової кооперації (20-і кінець 30-х рр. ХХ ст.);

III - інструкційно-статистичний (60-і - кінець 80-х рр. ХХ ст.);

IV - науково-аналітичний (з початку 90-х pp. XX ст.).

Основу першого періоду становлять праці дослідників дорадянської доби, другого і третього - опубліковані результати досліджень науковців радянського періоду, четвертого - вітчизняні публікації кінця XX - початку XXI століття.

Описово-аналітичний період у історіографії житлової кооперації $\epsilon$ особливо яскравим. Він відображає складні процеси становлення й перші здобутки кооперативних житлово-будівельних товариств і характеризується науковими працями, які, без перебільшення, можна назвати класикою кооперативної думки.

До їх числа належать роботи В. Бородаєвського, М. Бройдо, К. Вебб, М. Гібнера, Е. Левіна, О. Меркулова, Д. Полупанова, Л. Щеглової та ін. [1-6, 8-11].

Важливим джерелом для аналізу стану житлової кооперації Англії кінця XIX - початку XX ст. $\epsilon$ робота К. Вебб «Мирный переворот в экономической жизни. Кооперация в Великобритании», видана у 1910 р. [3]. Автор дослідила три варіанти кооперативного будівництва, детально описала діяльність найбільш відомих житловобудівельних товариств, навела цікаві статистичні дані. У своїй аналітичній статті «Строительная кооперация на Западе» (1911р.) М. Бройдо дав характеристику різних моделей житловобудівельних кооперативних організацій Англії початку ХХ ст. [2, с. 67].

Важливу інформацію про житлову кооперацію Німеччини названого періоду можна отримати 3 праці М. П. Гібнера «Система кооперации», опублікованої у 1911 р. у Москві [4]. Автор відобразив процес будівництва житлового будинку від придбання місця й складання архітектурного плану до передачі жилого приміщення члену кооперативного товариства. Він проаналізував можливі джерела залучення капіталу до житлово-будівельного кооперативу, порівняв розвиток житлової кооперації у Німеччині та Англії, підтвердив свої висновки відповідними статистичними даними.

Відомий російський дослідник кооперативного руху у галузі житлового будівництва початку
ХX ст. Д. Полупанов у 1915 р. у своїй статті «Кооперативное движение на Западе (Французская строительная кооперация)» звернув увагу на причини досить високого рівня розвитку французької житлової кооперації, називаючи найважливішими 3 них сприятливу державну політику i житлове законодавство [9]. Автор вважав, що сприяння житловій кооперації з боку держави було викликане не тільки необхідністю вирішення житлового питання, але й потребою зменшити соціальну напругу в середовищі робітничого класу. Дослідник на конкретному прикладі показав усі фінансові витрати члена кооперативного товариства, доводячи переваги такого механізму забезпечення громадян житлом.

В іншій праці - «Квартировладельческая кооперация» (1915 р.) - Д. Полупанов здійснив аналіз причин виникнення квартировласницьких (житлових кооперативних) товариств у Російській імперії на початку XX ст. [8]. Названі причини полягали у тому, що будинки, зведені житловими товариствами, вигідно відрізнялися своїм благоустроєм та новітнім обладнанням (ліфти, пральні, сушилки, централізована вентиляція тощо). Автор стверджував, що у будинках, збудованих кооперативними товариствами, квартири були пристосовані до потреб і побажань майбутніх власників. Перераховуючи переваги житлових кооперативів, Д. Полупанов об'єктивно писав і про наявні проблеми - дорожнечу квартир і відсутність дешевих кредитів. Дослідник, підтверджуючи свої висновки, наводив ціни на кооперативні квартири у Петрограді, схему виплат, суми першого внеску та щорічних платежів, умови іпотечного кредитування, аналізував джерела кредитів у Свропі. Подальший розвиток житлової кооперації, на думку автора, має визначатися вирішенням питання пошуку «дешевого» кредиту i розширенням прав учасників будівельного товариства.

Оцінку стану розвитку житлової кооперації у Російській імперії надає дослідження Товариства Споживчих товариств півдня Росії, що було опубліковане 1918 р. у Харкові [11]. Ця ж тема була предметом дослідження О. Меркулова, знайшовши своє відображення у публікації «Кооперативное движение в Росии» [6].

Аналіз розвитку кооперативного руху у країнах Західної Свропи зробили В. Бородаєвський у науковій праці «Кооперация среди славян» (1912. р.) та Л. Щеглова - у статті «Кооперативное движение на Западе (кооперативная жизнь в Западной Європе)», опублікованій у першому номері журналу «Вестник кооперации» за 1915 p. [1; 10]. 


\section{EKOHOMIKA}

Висновки. Дослідивши описово-аналітичний період в історіографії житлової кооперації, можна стверджувати, що саме житлова кооперація може бути одним із можливих механізмів вирішення гострої житлової проблеми в Україні. Да-

\section{БІБЛІОГРАФІЯ}

1. Бородаевский С. В. Кооперации среди славян / С. В. Бородаевский - С-Пб. : Типография редакции Периодических изданий Министерства Финансов, 1912. - 80 с.

2. Бройдо М. Строительная кооперация на Западе / М. Бройдо // Вестник кооперации. - 1911. Кн. 6. - С. 66-82.

3. Вебб E. Мирный переворот в экономической жизни. Кооперация в Великобритании. Обзор истории, теории и практики кооперативного движения в Англии, Шотландии и Ирландии / Е. Вебб. - Москва : Типо-литография товарищества И. Н. Кушнеров и К ${ }^{0}, 1910 .-230$ с.

4. Гибнер Н. П. Система кооперации / Н. П. Гибнер. - Москва : Типография А. Л. Будо, 1911. $147 \mathrm{c}$.

5. Левин Э. Что такое кооперация (критический очерк) / Э. Левин // Вестник кооперации. 1914. - Кн. 6. - С. 70-82.

6. Меркулов $A$. Кооперативное движение в России / А. Меркулов // Вестник кооперации. - на наукова робота акцентує увагу представників органів державної влади, науковців, громадськості на необхідності широкого інформування населення про великий потенціал житлових кооперативів та позитивний досвід їх функціонування.

1910. - Кн. 4. - С. 119-126.

7. Пантелеймоненко А. О. Становлення і розвиток кооперативних організацій аграрного сектору України (друга пол. XIX - поч. XXI ст.): дис. ... доктора екон. наук : 08.00.01 / Пантелеймоненко Андрій Олексійович. - Полтава, 2009. $413 \mathrm{c}$.

8. Полупанов Д. Квартировладельческая кооперация / Д. Полупанов // Вестник кооперации. - 1915. № 5. - C. 51-59.

9. Полупанов Д. Кооперативное движение на Западе (Французская строительная кооперация) / Д. Полупанов // Вестник кооперации. - 1915. № 2. - C. 43-51.

10. Щеглова Л. Кооперативное движение на Западе (Кооперативная жизнь в Западной Европе) / Л. Щеглова // Вестник кооперации. - 1915. - № 1. - C. 50-58.

11. Я. Р. и А. Д. Кооперация. Указатель литературы / Я. Р., А. Д. - Харьков : Типография Б. Бенчис, 1918. - $131 \mathrm{c}$. 